\title{
SÃo PAULO, VELHAS DESIGUALDADES, NOVAS CONFIGURAÇÕES ESPACIAIS
}

\author{
LúCIA MARIA MACHADO BÓguS \\ SUZANA PASTERNAK TASCHNER
}

\begin{abstract}
R E S U M O O presente artigo mostra estágio inicial do desenvolvimento de pesquisa financiada pelo PRONEX. Fornece uma primeira visão da "segregação" sócio-ocupacional na Grande São Paulo em 1991, evidenciando a distribuição residencial das categorias sócioocupacionais dos chefes de domicilio, faixa etária, cor, renda e escolaridade, além de algumas características domiciliares. Os mapas mostram uma grande concentração da chamada "lite dirgente" e profissionais de nivel superior na área central da capital e, de outro lado, os "trabalhadores de sobrevivência", que moram preferencialmente em determinadas áreas dos municípios periféricos. Como resultados gerais, os chefes da Grande São Paulo são ainda predominantemente masculinos (81,70\%), brancos (68,91\%), com baixa escolaridade (10,21\% sem nenhum ano de escolaridade formal). O trabalho espacializa estas variáveis, procurando observar niveis de segregação socioespacial. *
\end{abstract}

PALAVRAS-CHAVE Metropolização; segregação socioespacial; dinâmica intra-urbana.

\section{INTRODUÇÃO}

OBjetivos

Este trabalho analisa algumas tendências e características da dinâmica urbana de São Paulo. Integra um conjunto de estudos ${ }^{1}$ que pretendem avaliar, de maneira comparativa, os impactos do ajuste estrutural e da restruturação produtiva nas metrópoles do Sudeste (Rio de Janeiro, São Paulo e Belo Horizonte), no atual contexto de globalização.

A primeira seção descreve a evolução da dinâmica demográfica da Grande São Paulo nas últimas décadas e a evolução das condições de moradia popular no seu município central, para o qual havia dados disponíveis. A segunda seção espacializa algumas das variáveis sociodemográficas e sobre a moradia, visando mostrar, ainda que de maneira pontual (apenas para 1991), a estrutura socioespacial. Embora seja intenção da pesquisa analisar as transformações da estrutura social espacializada nas duas últimas décadas, este artigo restringe-se à análise dos chefes de família, em 1991, relativa a sexo, grupo etário, cor, educação, renda e categoria socioprofissional, e aos domicílios, quanto à condição de propriedade e à presença de infra-estrutura. Como material de investigação, foram usados dados dos chefes de família e dos domicílios do Censo Demográfico de 1991 (vide Nota Metodológica 1, em anexo).

A espacialização utilizada no artigo parte da classificação das diferentes regiôes da RMSP (Região Metropolitana de São Paulo) segundo a Emplasa (Empresa Metropolitana de Planejamento), onde são destacados oito vetores metropolitanos, que agrupam os 39
* Trabalho selecionado da sessão temática 6 - "Dinâmica socioespacial: há um padrão brasileiro de estruturação urbana?"
1 Tais estudos integram o projeto "Metrópole, desigualdades socioespaciais e governança urbana", financiados pelo MCT-PRONEX (Ministério de Ciência e Tecnologia Programa de Apoio a Núcleos de Excelência), 1998-2002. A pesquisa é coordenada pelo professor Luis Cesar de Queirós Ribeiro, do IPPUR/UFRJ, e articula-se em três eixos: Estudo das modificações na estrutura econômica; Estudo das desigualdades socioespaciais; Estudo das políticas locais. 
municípios integrantes da metrópole (vide Nota Metodológica 2, em anexo). O município da capital, que representa mais da metade da população metropolitana (9,81 dos 16,6 milhôes de habitantes em 1996), foi objeto de análise espacial mais detalhada, abrangendo os 96 distritos, enquanto para os outros municípios o total da área serviu como referência espacial para análise.

Dessa análise resultaram algumas constatações. Em primeiro lugar, a espacialização das categorias socioprofissionais, embora restrita aos chefes, mostra alto grau de segregação. As categorias "elite", "profissionais liberais" e "pequena burguesia" residem sobretudo na área central de São Paulo, enquanto os trabalhadores de sobrevivência se alocam preferencialmente na periferia. Há distritos na capital com mais de 50\% de chefes nessas categorias. Em segundo, a exclusão social visível por condiçōes de moradia - favelas, semteto - aumentou de maneira significativa nos últimos vinte anos, sobretudo no município central. A falta de saneamento em alguns vetores da Grande São Paulo, a metrópole mais rica do país, é assustadora: nos vetores Norte e Sudoeste mais de 50\% das moradias apresentam destino dos dejetos inadequado, e os vetores Oeste e Noroeste aproximam-se dessa cifra, com cerca de $48 \%$ dos domicílios sem saneamento. No município central a situação é melhor, mas está longe de ser satisfatória - mais de 10\% das casas tem saneamento deficiente e localizam-se sobretudo ao Norte e ao Sul, em áreas com risco ambiental significativo - represas e montanhas da Cantareira.

\section{INSPIRAÇốES INICIAIS: DESESTABILIZAÇÃo DE ÁrEAs INDUSTRIAIS, Novas Centralidades, DualizaÇÃo}

Após a Revolução Industrial, as cidades sofreram grande processo de crescimento. Este processo acentuou-se nos anos seguintes à Segunda Guerra Mundial, com o advento da chamada indústria fordista, com as grandes obras de reconstrução na Europa, e com a suburbanização americana. No chamado Terceiro Mundo, com o grande crescimento da metrópoles, em especial nas décadas de 1960 e de 1970, os temas da concentração espacial da força de trabalho e o da pobreza urbana foram objeto de diversas interpretaçóes. Na América Latina, alguns autores, como Nun (1969), sustentavam que existiriam dois tipos de superpopulação: um exército industrial de reserva e uma massa marginal, esta sim com forma de morar precária. Cardoso (1973) rejeitava essa diferenciação, identificando toda superpopulação com o exército industrial de reserva e negando o conceito de massa marginal. Oliveira (1981) ia além, ao afirmar que não só toda superpopulação integrava o exército industrial de reserva, como também que a sua concentração em atividades terciárias era parte do modo de acumulação urbano, apropriado à expansão do sistema capitalista no Brasil, e que não era, como escreveu Nun, disfuncional para o setor produtivo hegemônico. Assim, tanto este autor, como também Kowarick (1975) e Faria (1976), viam o crescimento do terciário "informal" como resultado normal do desenvolvimento capitalista no Brasil. Estas atividades não tipicamente capitalistas - e seu reflexo espacial - seriam úteis ao processo de acumulação, tanto por empregarem temporariamente uma reserva de força de trabalho, como por facilitarem a distribuição de produtos industrializados, por meio do pequeno comércio, reparos e manutenção, construção doméstica e por encomenda ( Taschner \& Mautner, 1982; Taschner, 1992; Mautner, 1991) etc. Nos anos 70, o tema da "periferização" associa-se ao da marginalidade ocupacional na constituição de nova forma de leitura do espaço urbano. Os agentes atuantes na formação desse espaço são mais bem identificados, e surgem inúmeros estudos sobre a atua- 
ção dos agentes imobiliários e a especulação fundiária (Smolka, 1992a, 1992b; Bógus, 1988; entre outros).

A questão da exclusão social hoje é analisada como conseqüência do chamado "processo de globalização", observado nas tendências econômicas atuais (Castel, 1997). Estas tendências seriam resultante de novas formas de organização da produção, após a "crise do fordismo". Pelas características dessas novas formas, elas não têm gerado emprego condizente com a quantidade e a qualidade da força de trabalho, sobretudo nos países mais atrasados. Tem-se, assim, uma exclusão distinta das anteriores. Formas de integração de inúmeras parcelas da força de trabalho nos setores hegemônicos parecem distantes e mesmo indiferentes ao capitalismo contemporâneo. Nesta perspectiva, a fragmentação espacial - o lugar dos excluídos - seria inevitável. As cidades seriam cada vez mais duais.

Segundo Van Kempen \& Marcuse (1997), as forças que moldam a estrutura interna das cidades podem ser agrupadas em três categorias gerais:

- forças em nível supra-urbano;

- forças internas e estruturais em relação ao padrão de distribuição intra-urbano, que obedecem à uma lógica comum em relação às pressóes de mudanças internas e externas; - forças específicas a cada cidade em particular.

Segundo Sassen (1991), as grandes cidades do mundo têm-se reestruturado como "cidades globais", em razão da nova divisão internacional do trabalho, ou seja, sofrendo o impacto da chamada globalização - combinação de novas tecnologias, aumento do comércio e da mobilidade, concentração do poder econômico e financeiro e redução do alcance do Estado do Bem-Estar Social. A hipótese central de Sassen é a "existência de vínculo estrutural entre o tipo de transformação econômica característica dessa cidade e a intensificação de sua dualização social e urbana" (Sassen, apud Preteceille, 1994, p.66).

Cardoso \& Ribeiro (1996) apontam as principais características dessas mudanças: desestabilização das antigas áreas industriais; criação de novas centralidades; transformação dos centros (CBDs - Central Business Districts) em áreas especializadas em serviços financeiros e atividades de controle e gestão; renovação residencial das áreas centrais ("gentrificação"); polarização social extrema - também chamada de dualização (Castells, 1989) -, entre elites e grupos empobrecidos, que compõem, em grande parte, os novos elementos do mercado de trabalho.

A reestruturação econômica característica da cidade global também contribui para a dualização - desta vez espacial - pelos mecanismos do mercado fundiário e imobiliário, já que a concorrência entre os diversos usos possíveis do espaço leva à apropriação cada vez mais exclusiva dos espaços mais valorizados - procurados - bem-atendidos etc., pelas funçóes que forneçam o maior lucro ou que correspondam ao consumo de luxo. (Preteceille, 1994, p.78)

Dentro deste quadro, qual seria a dinâmica urbana das metrópoles dos países em vias de desenvolvimento? Nas metrópoles do chamado Terceiro Mundo sempre existiram contrastes fortes entre as elites locais e os pobres marginalizados. São Paulo assiste a uma perda de emprego industrial, a uma redução do incremento demográfico, a um menor crescimento do PIB por habitante. A pobreza "visível" aumentou, com o crescimento de favelados e sem-teto. 
De outro lado, na região metropolitana de São Paulo os espaços socialmente mais polarizados correspondem, respectivamente, a 12,8 \% dos chefes (soma das categorias elite + pequena burguesia + profissionais liberais) e a 30,9\% dos trabalhadores manuais e de sobrevivência. Essas categorias residem em áreas diferenciadas, numa paródia dos círculos de Burgess, Escola de Chicago às avessas, onde os ricos estão no centro e os pobres na periferia (Bettin, 1982). (Vide Mapas, em anexo.) São espaços que marcam profundamente a estrutura metropolitana. Mas cerca de 56\% dos chefes residem sobretudo no anel intermediário, de forma indistinta (são os trabalhadores não-manuais, que se espalham na maior parte da área metropolitana).
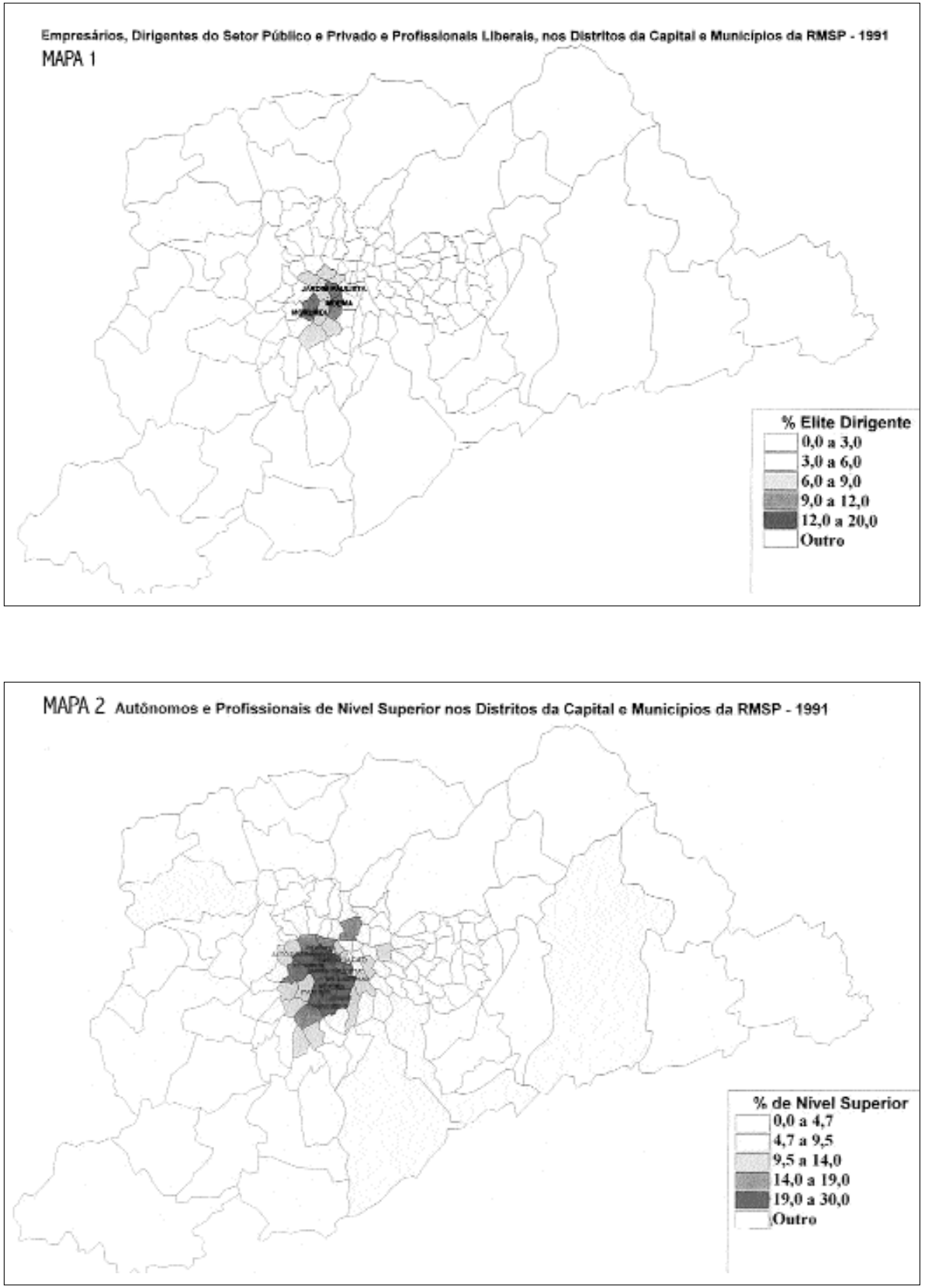


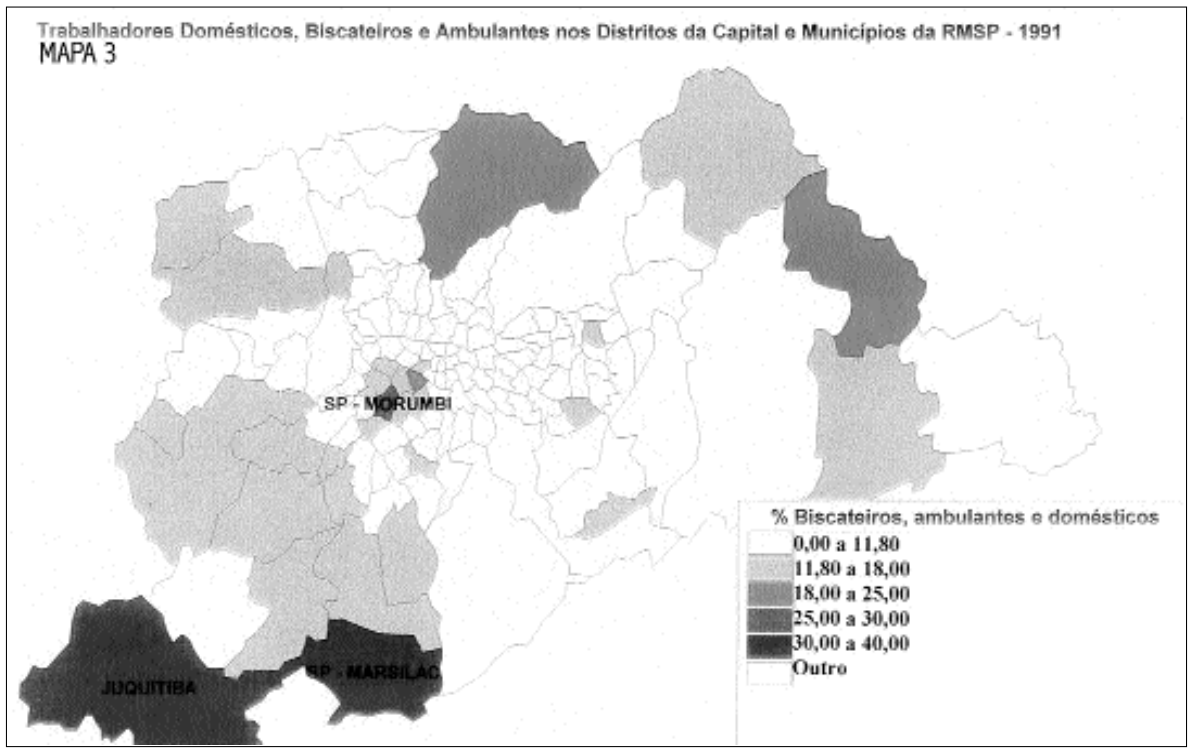

A distribuição de renda dos chefes na Grande São Paulo mostra que 7,42\% dos chefes encontram-se na faixa superior (mais de vinte salários mínimos), e mais de $25 \%$ deles têm renda até dois salários mínimos. Estes dados mostram uma polarização que resulta num espaço social específico.

Em relação às centralidades, conceituadas tanto como local com densidades de empregos terciários e como espaço simbólico, São Paulo assiste a uma mudança, embora falar em "gentrificação" em grande escala ainda seja prematuro. Nada se assemelha às Docklands londrinas, ao Battery Park americano, ao Puerto Madero argentino ou mesmo ao baiano Pelourinho. O centro de negócios e mesmo o simbólico migraram do Centro Histórico, deteriorado e com processos pontuais de renovação urbana, para a avenida Paulista, símbolo do capital financeiro dos anos 70, e, em seguida, para a avenida Faria Lima, centro de comércio e serviços que agora começa a abrigar bancos e financeiras (Nova Faria Lima), e, recentemente, para a avenida Engenheiro Luiz Carlos Berrini, sede de empresas terciárias, hotéis e comércio sofisticados desde meados de 80 e anos 90 (Frúgoli, 1998).

Nas regiōes tradicionalmente industriais (ABCD, Brás, Moóca, Belenzinho, Tatuapé, Ipiranga, Santo Amaro), já é nítido um esvaziamento das plantas industriais. Um detalhamento dos empregos nos anos de 1980 e 1991 vai permitir a mensuração desta perda.

O presente trabalho mostra alguns aspectos da estrutura socioespacial metropolitana. Se já se pode afirmar sobre o aumento dos sem-teto e dos favelados, não há ainda elementos que permitam afirmar sobre aumento da segregação, nem estabelecer relação causal entre segregação e globalização. A dualidade sempre existiu em São Paulo. Talvez sua explicitação espacial esteja mais nítida, com shopping centers e condomínios fechados. Neste ponto, certos traços urbanos seguem a classificação de Marcuse (1997): são cidadelas, enclaves e muitas vezes verdadeiros guetos, como algumas favelas.

\section{DINÂMICA DEMOGRÁFICA E ALTERNATIVAS DE MORADIA POPULAR}

Com uma área territorial de $5.070 \mathrm{~km}^{2}$ e população de 16,5 milhóes de habitantes (1998), a área metropolitana da Grande São Paulo mostra espaço bastante denso, embora com densidade demográfica desigualmente distribuída no espaço urbano. O cresci-

2 Este item integra o trabaIho "Tendências recentes na política de desfavelamento brasileira", apresentado no XIV Congresso Mundial de Sociologia, Montreal, Canadá, 26 de julho a 1 de agosto de 1998, por Suzana Pasternak Taschner. Para o presente artigo foram feitas algumas modificações. 
mento anual da região, entre 1991 e 1996, foi de 1,40\%, mostrando uma redução sensível: entre 1960 e 1970 a taxa de crescimento populacional da Grande São Paulo foi de 5,56\% ao ano; nos anos 70, de 4,46\%; entre 1980 e 1991, de 1,87\%; e entre 1991 e 1996, de 1,44\% ao ano. Como se vê, a taxa vem caindo a cada período.

Em relação à Grande São Paulo, o município de São Paulo apresentou uma população de 9,84 milhões de habitantes em 1996 (IBGE - Contagem do Meio da Década). Suas taxas de crescimento populacional são ainda mais fortemente declinantes que as da região metropolitana. Entre 1970 e 1980, a população paulistana aumentou em 3,67\% ao ano; entre 1980 e 1991, este ritmo caiu para 1,16\%; e no período 1991-1996, para 0,40\% ao ano. Cerca de 514 mil pessoas abandonaram a cidade entre 1986 e 1991. Por ano, foram em média 103 mil moradores que emigraram - um aumento de quase $50 \%$ em relação à média da década de 1980, quando cerca de 69 mil pessoas deixavam o município a cada ano (dados da Fundação Seade, publicados no jornal Folha de S. Paulo, 8.3.1997, p.3.1). O município de São Paulo só não viu sua população diminuir em termos absolutos porque seu crescimento vegetativo foi de 680 mil pessoas, maior ainda que a emigração.

O fator que mais pesou para a estagnação da população paulistana foi o deslocamento de antigos moradores da cidade para o entorno da capital. Não é por acaso que a região do Estado que mais cresceu foi o cinturão de municípios da Grande São Paulo, com saldo positivo migratório de 440 mil moradores entre 1991 e 1996. A região metropolitana, sem contar a capital, cresceu a uma taxa de 3,21\% ao ano, entre 1980 e 1991, e de 3,08\%, entre 1991 e 1996 (dados do IBGE, publicados no jornal Folha de S. Paulo, 1.3.1997), recebendo um saldo migratório positivo de 43.752 pessoas por ano na década de 1980, e de 87.992, entre 1991 e 1996. Esta cifra é maior que o saldo migratório para o interior do Estado, com média anual de 54 mil pessoas no período 1991-1996.

A periferização da populaçãao metropolitana, já evidente nos anos 80 , acentuou-se nos anos 90: os moradores mais pobres são impelidos para regiōes cada vez mais distantes, tanto para o entorno da capital, como para as cidades limítrofes. Além disso, o processo de desconcentração industrial, para regiôes com mão-de-obra mais barata e com menos impostos, continua. Aliam-se ao custo de mão-de-obra e ao custo da terra fatores como a migração de retorno e a fuga das classes médias para condomínios fechados nas cidades vizinhas.

Parte do parque industrial paulistano migrou, na década passada, para cidades do interior paulista e de outras regióes do Brasil. Investimentos federais em energia, estradas e indústria de base - tais como fábricas de aço em Minas Gerais e petroquímicas na Bahia e no Rio Grande do Sul - levaram investimentos privados para estas regiōes. No Estado de São Paulo, indústrias com "tecnologia limpa" fugiram da capital congestionada, sobretudo para um raio de cem $\mathrm{km}$ da capital, onde ficam cidades bem equipadas da época do café, como Campinas e São José dos Campos (The Economist, 27.3.1999). Segundo Célio Campolina Diniz, em 1970 a área metropolitana de São Paulo era responsável por $44 \%$ da produção industrial brasileira; em 1997, este percentual caíra para 25\% ("Brazil Survey”, The Economist, 27.3.1999, p.13). Considerando-se apenas o Estado de São Paulo, o peso relativo do interior no Valor de Transformação Industrial (VTI) aumentou de 23\%, em 1970, para 41\%, em 1990 (dados da Fiesp). Pesquisa recente da Fundação Seade (1998), segundo informações do seu site (www.seade.gov.br), mostrou que o interior paulista, atualmente com aproximadamente 17 milhóes de habitantes, responde por 50\% da produção industrial do Estado. Segundo a mesma pesquisa, realizada para orientar os programas de qualificação de mão-de-obra da Secretaria de Emprego e Relações de Trabalho, entre os investimentos privados para os próximos dois anos (1998 e 1999), apenas $19 \%$ se concentrarão na região metropolitana. 
Perante este quadro, percebe-se que o menor crescimento demográfico do município de São Paulo não significou melhoria de condiçôes de vida. A migração de atividades econômicas para o interior ampliou a pobreza urbana. Sinais visíveis da pauperização marcam a paisagem da cidade. Nos últimos dez anos, a chamada "cidade informal" cresceu mais que a "regular". Os novos domicílios em favelas, cortiços e loteamentos clandestinos superam os lançamentos do mercado imobiliário e a produção de unidades habitacionais pelo poder público.

Segundo o IBGE, entre 1980 e 1991, o município de São Paulo acusou um aumento de 1.150 mil pessoas e 480 mil domicílios. Neste período, cerca de 200 mil unidades foram licenciadas e 80 mil comercializadas por órgãos públicos (Barreto Silva \& Castro, 1997). Ou seja, cerca de 200 mil domićlíos que não atendiam a requisitos legais foram produzidos nestes onze anos, isto é, cerca de $44 \%$ do total de casas edificadas. Além disso, na época do Censo em 1991, cerca de 270 mil domićlios, concentrados sobretudo em áreas centrais do município, estavam vagos.

Entre 1980 e 1991, a participação relativa dos imóveis alugados no total de domicílios da cidade caiu de $40,02 \%$ para $28,74 \%$. Isto não implicou melhores condiçóes de moradia. Para reduzir os gastos com a moradia, muitas famílias "optaram" por favelas, por unidades em loteamentos clandestinos e mesmo por morar na rua. $\mathrm{O}$ número de sem-teto na cidade de São Paulo tem aumentado. Em 1991, eram 3.392 moradores de rua; em outubro de 1993, 4.500; em fevereiro de 1997, cerca de 5.400. Surge uma figura nova, a do desabrigado com teto, não só em São Paulo como também em Belo Horizonte, outra metrópole do Sudeste brasileiro. Trata-se de um morador de rua que possui casa na periferia, mas não pode arcar com o tempo e o custo das quatro horas de locomoção diária entre sua casa e o local de trabalho. Seu trabalho costuma ser ocasional, em geral catador de papel ou coletor de lixo urbano. Dorme na rua, sob marquises e viadutos, ao lado do seu fardo de papel, como garantia da sua propriedade, para evitar o roubo do produto do seu trabalho.

Além da favela, onde a obtenção da terra se dá por invasão, há outras alternativas irregulares de provisão de moradia. Uma delas é a compra de lotes em loteamentos clandestinos, feitos em zonas inadequadas, sem a infra-estrutura necessária e sem a possibilidade de obter a documentação de propriedade. Tanto nas favelas como nos loteamentos clandestinos, a construção da casa também é feita de modo irregular. Há, ainda, os que habitam cômodos ou unidades precárias de aluguel, provenientes da subdivisão ilegal de imóveis no centro da cidade ou da construção clandestina de imóveis para locação em lotes periféricos - os cortiços.

Essas formas de produção irregular da moradia existem desde o século passado, mas sua importância relativa tem se alterado no tempo. A forma mais antiga de habitação popular foi o cortiço, presente desde o início da industrialização. Em São Paulo, as primeiras informações sobre o cortiço são de 1893 (São Paulo, Município, 1894), quando foram pesquisados 65 cortiços em área central, com 1.320 residentes. No Rio de Janeiro, dados de Pimentel (apud Vaz, 1995) forneceram, para 1869, 642 cortiços, com 22 mil habitantes. Aparentemente, o fenômeno era mais gritante na antiga capital. A própria alcunha do cortiço - cabeça-de-porco - deve-se a um enorme cortiço situado próximo à estação de Estrada de Ferro Central do Brasil, o célebre "Cabeça de Porco", destruído pelo prefeito Barata Ribeiro, numa verdadeira ação policial, em 1893. Este cortiço foi arrasado para a abertura do túnel João Ricardo, cujas obras só foram concluídas em 1922. Seu nome se deve à forma característica da entrada do cortiço: um grande portal em arcada, ornamentado com a figura de uma cabeça de porco (Vaz et al., 1987). 
Em 1962, Lagenest (1962) estimou em 18\% o percentual da população da cidade de São Paulo moradora em cortiços. Em 1975, a Secretaria do Bem-Estar Social atualizou a estimativa, estabelecendo o percentual de moradores de cortiços em 9,3\%. Em 1993, a pesquisa Fipe/Sehab contou 24 mil cortiços em São Paulo, com 161 mil famílias moradoras e uma população de 600 mil pessoas, $6 \%$ da população paulistana.

As estimativas para os cortiços, ao contrário das de favela, são conflitantes. Seu universo é ainda pouco conhecido e explorado. O que se pode perceber é que, contrariamente ao que acontecia no início do século, a moradia precária de aluguel não mais se localiza predominantemente nas zonas centrais, mais bem servidas de infra-estrutura e mais próximas ao emprego. $\mathrm{O}$ "cortiço de periferia" é uma triste realidade atual. $\mathrm{O}$ autoconstrutor, no que resta do terreno após a edificação da casa, constrói uma seqüência de cubículos servidos por um único sanitário e os aluga.

Dos anos 40 até o fim dos anos 60, o loteamento periférico clandestino foi a forma dominante de obtenção da casa própria, por meio da autoconstrução. Embora o parcelamento irregular fosse notado como problema desde as primeiras décadas deste século, a única solução posta em prática pelo poder público foram as sucessivas anistias, entre 1916 e 1969. Em 1981, órgãos oficiais levantaram 3.567 loteamentos irregulares, correspondente a $23 \%$ da área total do município e a um terço da área urbanizada. Perante este quadro, criou-se uma categoria de lotes com exigências menores, para reduzir custos e permitir maior produção de lotes populares. Entretanto, o incentivo não foi suficiente: entre 1981 e maio de 1990, apenas 4.200 lotes foram submetidos à aprovação nesta categoria menos exigente. Entre 1988 e 1996, 13 mil lotes foram aprovados e 148 mil lotes clandestinos foram identificados. Apenas $9 \%$ dos lotes e $25 \%$ da área loteada nestes oito anos foram legais... (Silva \& Castro, 1997, p.39). Na presente década, o fenômeno do loteamento clandestino voltou, sobretudo na região de proteção aos mananciais. Entre 1984 e 1990, foram identificados, nessa área, 105 loteamentos clandestinos que ocupavam 1.866,5 hectares (cerca de 50\% da área clandestina identificada).

Na cidade de São Paulo, o fenômeno "favela”, embora presente nos anos 40, só vai se desenvolver em larga escala nos anos 70. "Em 1957, apurava-se na capital de São Paulo um total de 141 núcleos, com 8.488 barracos e cerca de 50 mil favelados" (Finep/GAP, 1983, p.6). Em 1973, os aglomerados favelados já somavam 542, com 14.650 domicílios e quase 72 mil pessoas (1,09\% da população municipal). Em 1980, eram 80.535 moradias, com 440 mil pessoas (5,18\% da população da cidade). Segundo o Censo de favelas de 1987, o total de assentamentos favelados em São Paulo chegou a 1.592, com 150 mil casas abrigando 813 mil pessoas (8,92\% da população da capital). Em 1993, data da última pesquisa, o número de moradias faveladas atingiu 378,6 mil, com 1,9 milhões de pessoas, 19,8\% da população municipal.

Em duas décadas - de 1973 a 1993 - a população moradora em favelas no município de São Paulo passou de $1 \%$ para quase $20 \%$ da população total.

No processo de ocupação do espaço, quando as próprias favelas tornam-se inacessíveis (a mercantilização das terras e casas em invasões já começa a se tornar prática comum na cidade - em 1993, 41\% dos chefes de família declararam ter pago por seu lote contra 4,3\% em 1987), surgem novos tipos de invasão: debaixo de pontes e viadutos; em calçadas de vias expressas; em jardins e praças públicas; além da verticalização de unidades em favelas estruturadas e da população que se abriga nas ruas e avenidas, sem local fixo, navegando de forma incessante nos espaços públicos da cidade. 
Em São Paulo não existem estudos conclusivos sobre o número da população de rua. Foram realizadas duas investigaçóes no município. Uma delas (Vieira, 1992) foi feita percorrendo ruas na área central da cidade, durante o inverno de 1991 (junho a agosto de 1991). A outra foi anterior, baseada num estudo realizado no plantão da Supervisão Regional das Administrações Sé e Lapa em fevereiro de 1991. Uma investigação mais recente (em outubro de 1993) visou contar as crianças e adolescentes para quem a rua constitui fonte de geração de renda e contexto de vida.

Na pesquisa realizada durante o inverno de 1991, identificaram-se 329 pontos de pernoite com 3.392 pessoas, e número médio de pessoas por ponto variando entre 3 e 14 (Kohara \& Almeida, 1995); o grupo modal possuía entre 2 e 5 pessoas (34\%); 21\% eram compostos entre 6 a 10 pessoas; 200 pontos de dormida eram ruas ou avenidas, 51, praças públicas, 39 viadutos, e os outros distribuíam-se em canteiros de prédios, terrenos vagos etc. Quanto ao sexo, 92\% eram homens, 50\% eram brancos e $85 \%$ exerciam alguma atividade econômica, muitas vezes registrada. Grande parcela estava na rua há mais de seis meses (56\%).

A pesquisa sobre as crianças de rua de 1993 encontrou um total de 4.529 menores vivendo pelas ruas de São Paulo durante o dia. À noite, são 895. Foram classificados como em "situação de rua" toda criança e adolescente trabalhando (como ambulante, catador de papel, guardador de carro, carregador de feira etc.), mendigando ou perambulando pelas ruas. Como se vê, apenas 19,5\% não têm casa e dormem na rua. O total de menores do sexo masculino em situação de rua é 4,5 vezes maior que o do sexo feminino.

Monsenhor Júlio Lancelotti, vigário episcopal do povo de rua na Arquidiocese de são Paulo, citou, em uma entrevista a alunos da FAU/USP: "Uma vez eu perguntei a um menino da rua o que era a rua. E ele disse que a rua era um lugar cheio de portas e que ele não podia entrar em nenhuma. Uma criança. Não que todos tenham essa visão. Acredito que o povo da rua dentro de uma casa é o mesmo que nós na rua, porque é toda uma questão de espaço, eles criam o espaço, limitam, constroem aquele espaço. Mas são espaços sem limites. Você muda de um para o outro sem ser pela porta. Não há paredes. O povo da rua se movimenta atrás de comida, de relaçôes humanas, por isso que nós procuramos trabalhar com eles a relação humana, como restauradora da dignidade. Quem é que conversa com o povo da rua?" (entrevista à Revista Caramelo, n.9, p.42, 1997).

Numa cidade de 9,8 milhôes de habitantes, com 2,7 milhôes de domicílios, entre os quais se computam pelo menos 600 mil pessoas em cortiços, 1,9 milhóes de favelados, uma população de número desconhecido ocupando loteamentos irregulares e casas fora do padrão considerado aceitável (em 1989 a estimativa de casas fora do padrão era de 350 mil, $15 \%$ do total de domicílios) mostra o retrato de uma metrópole excludente, onde mais da metade dos seus habitantes mora numa cidade clandestina, precária, onde a população de rua - pequena em termos relativos, mas crescente - é apenas a parte aparente de um dos círculos dantescos da comédia urbana.

\section{VARIÁVEIS SOCIODEMOGRÁFICAS E HABITACIONAIS: CARACTERIZAÇÃO E ESPACIALIZAÇÃO}

No que diz respeito aos dados sistematizados para análise, as variáveis sociodemográficas pesquisadas, como apontado anteriormente, referem-se aos chefes de família em 1991. São elas: sexo, grupo etário, cor, educação, renda e categorias sócio-ocupacionais. 
Em relação ao domicílio, analisaram-se as condições de ocupação (próprio, alugado, cedido, outros) e algumas informaçóes sanitárias em relação ao abastecimento de água, destino do lixo e dos dejetos.

Tabela 1 - Região Metropolitana de São Paulo. População e taxas geométricas de crescimento anual, segundo vetores

\begin{tabular}{lrrrrr}
\hline Vetores & & População & & \multicolumn{2}{c}{ Taxas (\%) } \\
& & & & $1980 / 91$ & $1991 / 96$ \\
\hline Centro & 8.967 .769 & 10.193 .843 & 10.434 .150 & 1,29 & 0,47 \\
Noroeste & 997.978 & 493.291 & 614.947 & 5,17 & 5,17 \\
Oeste & 152.436 & 293.218 & 362.800 & 6,76 & 4,35 \\
Sudoeste & 287.466 & 481.934 & 562.869 & 5,08 & 3,58 \\
Sudeste & 1.652 .781 & 2.045 .227 & 2.227 .904 & 2,15 & 1,73 \\
Leste & 519.037 & 816.481 & 982.423 & 4,63 & 3,77 \\
Nordeste & 579.227 & 861.877 & 1.064 .899 & 4,05 & 4,32 \\
Norte & 132.031 & 248.147 & 310.403 & 6,52 & 4,58 \\
Total & 12.588 .725 & 15.416 .416 & 1.656 .035 & 1,86 & 1,44 \\
\hline
\end{tabular}

Fonte: IBGE - Censos demográficos de 1980 e 1991. Contagem populacional de 1996.

A Tabela 1 mostra a população metropolitana nos oito vetores estudados e as taxas de crescimento anuais da população em cada vetor. Como já foi dito no Item 2 , a taxa de crescimento populacional metropolitana está diminuindo. Esta diminuição, entretanto, não se dá de forma uniforme pelo território. A redução da taxa total deve-se sobretudo à redução do vetor Centro (Capital e Osasco), com taxas entre 1991 e 1996 de 0,38\% e $1,88 \%$ anuais, respectivamente. Há vetores em que as taxas desde 1980 tem-se mantido com valores altos, como o vetor Noroeste (Barueri, Cajamar, Carapicuíba, Pirapora e Santana do Parnaíba). E no vetor Nordeste (Arujá, Guarulhos e Santa Isabel), ela aumentou nos últimos anos. A região do Estado que mais cresceu entre 1991 e 1996 foi o cinturão de municípios da Grande São Paulo; nele se distingue Guarulhos, como o município paulista que mais cresceu em termos absolutos nos anos 90 , com taxa anual de $4,31 \%$ e crescimento absoluto de 186 mil pessoas, das quais cerca de 80 mil por migração. Na Tabela 1 observa-se que as taxas geométricas de crescimento populacional continuam altas em todos os vetores, com valores superiores a $4 \%$, com exceção do Centro e do Sudeste (ABCD). Sem a capital, os municípios da região metropolitana cresceram 3,08\% anuais entre 1991 e 1996 (3,2\% entre 1980 e 1991).

A periferização da população metropolitana, já evidente nos anos 80 , acentua-se nos anos 90: moradores mais pobres são expelidos para regiōes cada vez mais distantes. Entre 1980 e 1991, a metrópole cresceu, em números absolutos, cerca de 2,83 milhōes de pessoas. Deste total, $60 \%$ deveu-se ao crescimento dos outros municípios da Grande São Paulo. O crescimento metropolitano entre 1991 e 1996 foi de 1,14 milhôes, dos quais apenas $16 \%$ deveu-se ao crescimento da capital.

Dentro do tecido urbano do município de São Paulo, a periferização também evi-

3 Para a definição dos anéis, ver o artigo de Taschner, S. P., na Revista Brasileira de Estudos de População, $7 / 1,1990$. dencia-se. A Tabela 2 mostra que praticamente todo o crescimento paulistano deu-se no chamado anel periférico ${ }^{3}$ na década de 1980 . O aumento da população da capital não chegou a 200 mil habitantes entre 1991 e 1996. 
L Ú C I A M. M. B Ó G U S E S U Z A N A P. T A S C H N E R

Tabela 2 - Município de São Paulo: incrementos e taxas de crescimento, 1960-1991

\begin{tabular}{lrrrrrrrrr}
\hline Anel & \multicolumn{9}{c}{ Incrementos } \\
& $1960-70$ & \multicolumn{1}{c}{$\%$} & $1970-80$ & \multicolumn{1}{c}{$\%$} & $1980-91$ & \multicolumn{1}{c}{ Taxas (\%) } & $1960-70$ & $1970-80$ & $1980-91$ \\
\hline Central & 22.635 & 1,02 & 84.531 & 3,29 & -51.838 & $-4,57$ & 0,72 & 2,23 & $-1,17$ \\
Interior & 5.168 & 0,23 & 91.648 & 3,57 & -76.036 & $-6,71$ & 0,08 & 1,26 & $-0,93$ \\
Intermediário & 324.375 & 14,64 & 182.433 & 7,10 & -59.087 & $-5,21$ & 2,79 & 1,28 & $-0,36$ \\
Exterior & 910.791 & 41,11 & 792.046 & 30,83 & 257.237 & 22,69 & 5,52 & 3,13 & 0,75 \\
Periférico & 952.372 & 43,00 & 1.417 .953 & 55,20 & 1.063 .396 & 93,8 & 12,90 & 7,42 & 2,99 \\
Município & 2.215 .341 & 100,00 & 2.568 .691 & 100,00 & 1.133 .672 & 100,00 & 4,79 & 3,67 & 1,15 \\
\hline
\end{tabular}

Fonte: IBGE - Censos demográficos de 1960, 1970, 1980 e 1991.

Com referência à chefia do domicílio, as mulheres representam apenas 18,3\% dos chefes, embora trabalhos recentes apontem para um aumento crescente da chefia feminina nas últimas décadas (Montali,1997). No município central o percentual é maior; 20,26\% dos domicílios eram chefiados por mulheres. E a distribuição intra-urbana na capital era bastante peculiar - no Centro (distritos de Bela Vista, Bom Retiro, Brás, Pari, República e Santa Cecília) a chefia feminina chega a 34\%. A chefia é atribuída pelos entrevistados a um membro do grupo domiciliar. Num país patrilinear, onde juridicamente até pouco tempo atrás a cabeça do casal era sempre o indivíduo do sexo masculino, os moradores costumam atribuir ao homem, sempre que existe, a condição de chefe. Assim, no Centro, para se ter o elevado percentual de chefes femininas, é muito provável que se tratem de domicílios com viúvas, mulheres sós e/ou mulheres sem companheiros. E por que isso se daria preferencialmente no Centro? Hipóteses plausíveis: estrutura etária mais velha, que favorece um excedente feminino, presença de cortiços e kitchinettes (seguindo a literatura, que associa chefia feminina à pobreza, portanto à moradia pior).

Essa população de chefes é majoritariamente branca, observando-se a existência de alguns enclaves étnicos na Região Metropolitana e no município-sede, como é o caso dos distritos paulistas de Jardim Ângela, Jardim Helena, Cidade Tiradentes, Itaim Paulista, Itaquaquecetuba e Guaianazes e dos municípios de Ferraz de Vasconcelos (vetor Leste), Barueri (vetor Noroeste) e Francisco Morato (vetor Norte), todos eles com percentuais de chefes não-brancos superiores a 50\%.

De outro lado, cabe mencionar que os percentuais de chefes não-brancos são muito reduzidos (inferiores a 10\%) nos distritos de Alto de Pinheiros, Perdizes, Moema, Jardim Paulista, o que permite estabelecer uma relação entre renda, escolarização, cor e local de residência no espaço urbano. Esta relação é reforçada quando se observa o percentual de chefes de renda baixa, de até dois salários mínimos, nos distritos e municípios com alto percentual de chefes não-brancos: $34 \%$ dos chefes no Jardim Helena e no Itaim Paulista; 27\% em Cidade Tiradentes.

No que se refere à escolarização, expressa em anos de estudo, o grupo modal situase na faixa de um a quatro anos de estudo (40,6\% dos chefes), evidenciando níveis extremamente baixos de educação formal, agravados se considerarmos o índice de cerca de $10 \%$ dos chefes sem escolarização alguma. No outro extremo, cabe apontar que 13,6\% dos chefes residentes na RMSP possuem nível superior, com 12 ou mais anos de estudos (Tabela 3). 


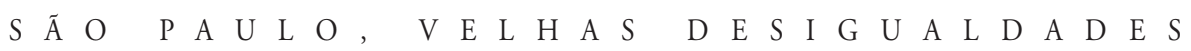

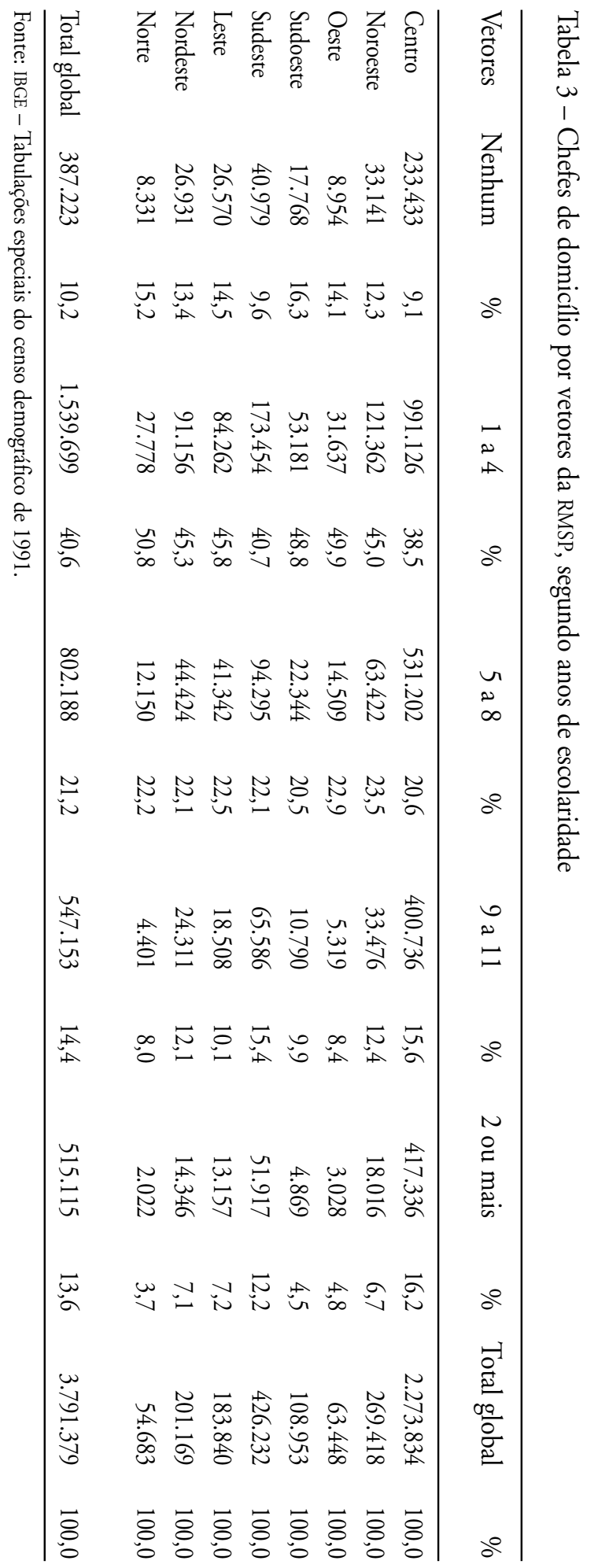


No vetor Centro estão os percentuais mais elevados de chefes com escolaridade de nível superior $(16,2 \%)$ e no vetor Norte encontram-se os percentuais mais baixos de chefes com tal nível de escolaridade (3,7\%).

Os chefes de domicílio sem escolarização concentram-se nos vetores Sudoeste (16,3\% de chefes com nenhuma escolaridade) e Norte (15,2\% de chefes nesta condição). Somando-se a esses percentuais os chefes com até quatro anos de estudo, temos os alarmantes percentuais de $66,0 \%$ de chefes com baixa escolaridade no vetor Norte e, $65,1 \%$, no vetor Sudoeste (Tabela 3).

Com relação à renda dos chefes (Tabela 4), 25,35\% podem ser classificados como pobres (com renda mensal de até dois salários mínimos). A concentração de chefes pobres ocorre, particularmente, no vetor Oeste (30,1\% do total de residentes). Pode-se assinalar, ainda, que nos vetores Centro e Sudeste o percentual de chefes de baixa renda é da ordem de $20 \%$.

Considerando-se como chefes de "renda média" aqueles situados na faixa de cinco a vinte salários mínimos de renda mensal, observa-se um total de 37,4\% das chefias nessa condição, o que aponta para a existência de uma "classe média" numerosa e relativamente dispersa no tecido metropolitano. A maior concentração de chefes de "renda média" ocorre nos vetores Centro (33,6\% do total de residentes) e Sudeste (36,3\% do total de residentes). Deve-se ressaltar que o vetor Sudeste reúne os principais municípios industriais paulistas - hoje, também, centros importantes nos ramos do comércio e prestação de serviços - e concentra os maiores percentuais de chefes de "renda média" da região metropolitana, enquanto os maiores percentuais de chefes com alta renda (superior a vinte salários mínimos) acham-se concentrados no vetor Centro, especialmente no município de São Paulo (cerca de 241 mil chefes de família).

Tabela 4 - Chefes de domicílio (\%) por vetores da RMSP, segundo faixas de renda agrupadas

\begin{tabular}{lcccc}
\hline Vetores & $\begin{array}{c}\text { 0 a 2 salários } \\
\text { mínimos }\end{array}$ & $\begin{array}{c}\text { de 2 a 5 } \\
\text { salários mínimos }\end{array}$ & $\begin{array}{c}\text { de 5 a 20 } \\
\text { salários mínimos }\end{array}$ & $\begin{array}{c}\text { Mais de 20 } \\
\text { salários mínimos }\end{array}$ \\
\hline Centro & 20,2 & 34,6 & 33,6 & 7,8 \\
Noroeste & 25,5 & 45,1 & 22,7 & 3,5 \\
Oeste & 30,1 & 43,4 & 19,2 & 3,1 \\
Sudoeste & 25,4 & 42,8 & 26,4 & 1,8 \\
Sudeste & 19,9 & 35,5 & 36,3 & 4,9 \\
Leste & 32,9 & 40,3 & 20,6 & 2,1 \\
Nordeste & 24,8 & 41,6 & 26,8 & 2,8 \\
Norte & 26,3 & 46,8 & 22,3 & 1,7 \\
Total & 25,3 & 25,4 & 37,3 & 7,4 \\
\hline
\end{tabular}

Fonte: IBGE - Tabulaçóes especiais do Censo Demográfico de 1991.

Vale a pena notar - numa primeira tentativa de associação dos dados - que somados os chefes das três categorias ocupacionais superiores (elite dirigente, pequena burguesia e profissionais de nível superior), obtém-se o total de 271.459 pessoas, a maioria dos quais deve auferir rendimentos superiores a vinte salários mensais.

No caso do município de São Paulo, observa-se uma expressiva concentração desses chefes de categorias ocupacionais superiores em distritos como Jardim Paulista (com $58,8 \%$ de chefes nas camadas superiores), Moema (57,8\%), Alto de Pinheiros (53,7\%), 
Pinheiros (48,8\%), Perdizes (51,8\%), Vila Mariana (48,6\%), Itaim Bibi (47,4\%), Morumbi (45,8\%), Campo Belo (45,3\%) e Consolação (44,0\%). (Vide Mapas em anexo.) São distritos com alta concentração de população rica; por exemplo, Morumbi conta com 42\% dos chefes com renda de mais de vinte salários mínimos; Jardim Paulista, com 40\%; Alto de Pinheiros, com 36\%; e Itaim Bibi, com 32\%.

No extremo oposto, no quadro dos trabalhadores da sobrevivência, evidencia-se a já mencionada polarização entre riqueza e pobreza na área metropolitana. Considerando-se apenas os distritos com acima de $20 \%$ de chefes residentes situados nessa categoria, observa-se que eles residem nas áreas periféricas, tanto do município de São Paulo, como da Região Metropolitana. Complementarmente, é relativamente pequena a presença desses contingentes de trabalhadores da sobrevivência nos demais distritos do município-sede, bem como a de chefes de domicílio pertencentes às camadas superiores nas áreas de periferia anteriormente mencionadas.

De fato, enquanto entre os chefes de domicílio residentes no vetor Central 19,0\% pertencem às categorias ocupacionais de nível superior, no vetor Norte apenas 7,9\% dos chefes situam-se nessas categorias (Tabela 5). Nos demais vetores - com exceção feita ao vetor Sudeste, que possui 15,8\% de chefes com ocupaçōes de nível superior - o percentual de chefes das categorias ocupacionais superiores situa-se entre $9 \%$ e $10 \%$ do total de chefes residentes.

Tabela 5 - Chefes de domicílio, por vetores da RMSP, segundo categorias sócio-ocupacionais agrupadas, em porcentagem

\begin{tabular}{lccc}
\hline Vetores & $\begin{array}{r}\text { Elite dirigente, pequena } \\
\text { burguesia, nível superior }\end{array}$ & $\begin{array}{r}\text { Não-manuais de nível } \\
\text { médio, comércio e serviços }\end{array}$ & $\begin{array}{c}\text { Manuais da indústria e serviços, } \\
\text { trabalhadores de sobrevivência }\end{array}$ \\
\hline Centro & 19,00 & 55,60 & 24,90 \\
Noroeste & 9,10 & 54,40 & 36,00 \\
Oeste & 9,40 & 47,60 & 40,90 \\
Sudoeste & 8,60 & 49,70 & 39,60 \\
Sudeste & 15,80 & 53,70 & 30,20 \\
Leste & 10,30 & 48,00 & 37,00 \\
Nordeste & 10,90 & 52,90 & 34,90 \\
Norte & 7,90 & 48,80 & 42,50 \\
Total & 16,40 & 54,10 & 28,60 \\
\hline
\end{tabular}

Fonte: IBGE - Tabulaçóes especiais do Censo Demográfico de 1991.

Detalhando um pouco mais as informações acerca da distribuição espacial dos trabalhadores manuais e da sobrevivência (vide Mapas), observa-se que eles se concentram no vetor Oeste (municípios de Cotia, Itapevi, Jandira e Vargem Grande, classificados como municípios-dormitórios da RMSP) e no vetor Norte (municípios de Francisco Morato, Franco da Rocha, Caieiras e Mairiporã, também "dormitórios” da região metropolitana). Estes dois vetores situam-se, por sua vez, entre os que mais cresceram no período 19911996 (4,35\% e 4,58\%, respectivamente, em seu conjunto), apontando uma vez mais para o processo de periferização da pobreza. Outro vetor que apresentou taxas de crescimento populacional importantes, no mesmo período, foi o Noroeste ( $4,35 \%$ ao ano). Trata-se neste caso de área residencial onde se localizam, de forma segregada, grandes condomínios fechados (Alphaville) ao lado de conjuntos residenciais populares e favelas. 
Ainda no que se refere à distribuição espacial das categorias ocupacionais na região metropolitana de São Paulo, esse primeiro recorte analítico permite apontar para a dispersão dos trabalhadores de nível médio (trabalhadores não-manuais e do comércio e serviços), por todos os vetores da metrópole, com alguma predominância no vetor Centro, onde se concentram a elite dirigente e os profissionais de nível superior.

Em relação às características domiciliares, foram apuradas variáveis relativas à condição de ocupação das casas, assim como algumas informaçōes sobre saneamento.

Sobre a propriedade domiciliar, $66,92 \%$ das moradias da região metropolitana são próprias $(58,32 \%$ totalmente próprias e $8,60 \%$ apenas com a construção própria). Em 1980 52,65\% das moradias metropolitanas eram próprias. Em 1980, as categorias de apuração dividiam-se em próprias totalmente quitadas (42,32\%) e em processo de aquisição $(10,33 \%)$. Em 1991 tem-se definidas a propriedade total e a propriedade apenas da construção, podendo o lote ser cedido, alugado ou invadido. $\mathrm{O}$ aluguel e a cessão de terras para fins domiciliares são eventos pouco freqüentes. A maior probabilidade seria de que as unidades onde apenas a construção é própria sejam casas construídas em terrenos invadidos, ou seja, domicílios favelados. Pelo Censo de 1991, o número de casas faveladas na RMSP era de 203.833, em 1.021 favelas (Anuário Estatístico de 1992). Pelos dados censitários relativos aos domicílios, há 362.233 moradias com apenas a construção própria, portanto uma diferença de 158,4 mil domicílios.

Há fortes indícios de que as favelas recenseadas estejam subdimensionadas. O IBGE computa, na sua publicação sobre favelas, apenas as unidades em assentamentos com mais de cinqüenta casas. Não se pode afirmar, entretanto, que o número de domicílios favelados metropolitanos seja exatamente 362 mil em 1991 - número de unidades com apenas a construção própria, o que daria 8,6\% da moradias metropolitanas em favelas. É provável que muitos domicílios favelados tenham sido computados como totalmente próprios. Pelo menos, os dados relativos ao município da capital, sobre o qual existe um cadastro de favelas mais detalhado, indica esta possibilidade. Em 1993, dados da Sehab-SP registravam, para o município da capital, 378.683 casas faveladas. Os dados censitários de 1991, observando-se a categoria "apenas a construção própria", fornecem 178.744 casas. As informaçōes sobre favelas do IBGE em 1991 fornecem o total de 135 mil moradias em favelas para capital. Tem-se, assim, três estatísticas distintas, com o número indicado pelo cadastro de favelas Sehab-SP/Fipe bastante superior aos dois indicados pelo Censo.

A análise comparativa das condições de ocupação das moradias metropolitanas mostra uma diminuição da proporção de casas alugadas entre 1980 (37,57\%) e 1991 (22,78\%). O percentual de moradias cedidas manteve-se mais estável (8,40\% em 1980 e $9,72 \%$ em 1991). A década foi marcada por crises econômicas e mudanças na legislação do inquilinato. Este aumento de 14 pontos percentuais nos domićlios próprios (de 52,65\% em 1980 para 66,82\% em 1991) não deve significar melhores condições financeiras, expressas por propriedade da moradia. O financiamento para compra de casas foi pequeno na década, em 1986 o BNH faliu, e desde 1984 funcionava de forma precária. A grande probabilidade é de que este aumento do percentual de casas próprias deva-se ao aumento do número de casas autoconstruídas e em favelas. A relação inversa entre renda e propriedade domiciliar, rara nos países desenvolvidos e freqüente no Brasil, é verificada na observação do percentual de aluguel por vetor da RMSP: no vetor Centro, onde se tem a maior renda e a maior concentração da elite dirigente mais pequena burguesia mais profissionais de nível superior, está uma das maiores porcentagens de casas alugadas (32,03\%). O vetor Sudeste, que compreende o Grande ABC, com a segunda maior con- 
centração das categorias socioprofissionais mais altas, assim como da faixa de renda acima de vinte salários mínimos ( $4,9 \%$ dos chefes, inferior apenas à encontrada no vetor central), apresenta também percentual relativamente alto de moradias alugadas: $23,31 \%$. De outro lado, nos vetores mais pobres - Oeste, Leste e Norte - o percentual de casas alugadas era de $17,47 \%, 19,36 \%$ e 15,13\%, respectivamente. No vetor Norte, onde apenas $1,7 \%$ dos chefes tem renda superior a vinte salários mínimos, o percentual de moradias cedidas ultrapassa o de outros vetores, atingindo $26,79 \%$ do total de casas. Lembramos que no vetor Oeste (Cotia, Itapevi, Jandira e Vargem Grande) e no Norte (Francisco Morato, Franco da Rocha, Caieiras e Mairiporã), concentram-se os trabalhadores manuais e de sobrevivência. Estes vetores são os que apresentaram taxas de crescimento elevadas entre 1980 e 1991 (6,76\% e 6,52\%, respectivamente) e continuam com taxas altas entre 1991-1996 (4,35\% e 4,58\%). Percebe-se que o crescimento se dá com más condições domiciliares, o que corrobora a hipótese da periferização da pobreza.

Estas más condições domiciliares são confirmadas pelas condições de saneamento. A Tabela 6 mostra a espantosa porcentagem de $64,21 \%$ de casas com instalaçóes sanitárias inadequadas no vetor Norte. O vetor Sudoeste (Embu, Embu-Guaçu, Itapecerica da Serra, Juquitiba, São Lourenço e Taboão da Serra) também tem percentual alto de moradias sem instalaçôes sanitárias adequadas, 53,86\%, assim como o Oeste, com 49,74\% das casas deficientes sanitariamente.

Tabela 6 - Infra-estrutura adequada, por tipo de equipamento, segundo vetores da RMSP, em porcentagem

\begin{tabular}{lccc}
\hline Vetores & Água & Saneamento & Lixo \\
\hline Centro & 96,25 & 77,49 & 94,69 \\
Noroeste & 93,43 & 70,99 & 94,49 \\
Oeste & 93,73 & 50,26 & 87,71 \\
Sudoeste & 95,89 & 46,14 & 90,00 \\
Sudeste & 93,58 & 60,67 & 90,41 \\
Leste & 91,58 & 61,89 & 87,86 \\
Nordeste & 93,58 & 60,67 & 90,41 \\
Norte & 84,04 & 35,79 & 70,44 \\
Total & 95,75 & 74,27 & 93,78 \\
\hline
\end{tabular}

Fonte: IBGE - Tabulaçóes especiais do Censo Demográfico de 1991.

Embora as condições sanitárias tenham melhorado entre 1980 e 1991, chama a atenção que 25,73\% dos domicílios da Grande São Paulo apresentassem instalaçôes sanitárias consideradas inadequadas e/ou ausentes em 1991 ( são consideradas adequadas apenas as instalaçôes sanitárias não-coletivas, com destino final dos dejetos na rede pública de esgotos e/ou fossa séptica). Este percentual era de 36,80\% em 1980. Houve melhoria das condiçôes de saneamento na metrópole, mas o fato de um quarto das casas metropolitanas apresentarem instalações sanitárias inadequadas no início da década de 1990 é alarmante. Esse mesmo quadro pode ser observado nas duas outras regióes metropolitanas do Estado de São Paulo - Campinas e Santos, onde, segundo survey realizado em 1995, 26\% dos domicílios da região metropolitana de Campinas e 28\% da de Santos não possuíam ligação domiciliar de esgoto (Bógus, 1997). 
O investimento feito pelo poder público no abastecimento de água potável já se refletia na proporção de $86,39 \%$ dos domićlios com abastecimento de água correto em 1980. Esta proporção sobe para $95,75 \%$ das moradias metropolitanas em 1991. Foi considerada instalação de água adequada a oriunda de rede geral e/ou poço com canalização interna. O vetor menos favorecido é o vetor Norte, com 15,96\% das casas apresentando abastecimento de água inadequado.

A Tabela 6 refere-se ainda ao destino do lixo doméstico - se coletado, queimado, enterrado, jogado no rio ou na terra. Apenas o lixo coletado, direta ou indiretamente, foi considerado como adequado. Na RMSP, 93,78\% do lixo doméstico era coletado em 1991. Cabe ressaltar que não está computada a freqüência da coleta nem o destino final do lixo coletado. O vetor Norte novamente aparece com condiçôes precárias: 29,56\% dos seus domicílios têm destino do lixo doméstico inadequado.

\section{ALGUMAS CONSIDERAÇÕES FINAIS: HIPÓTESES E INDAGAÇÕES}

Tratando-se de trabalho em andamento, essa primeira aproximação dos dados constitui fonte de indagaçôes e instiga investigações mais detalhadas acerca dos processos socioespaciais em curso na RMSP.

Em relação aos processos de segregação - exclusão social -, há fortes indícios de seu aprofundamento, no quadro de uma metrópole complexa, internacionalizada ou globalizada, onde ao lado de enormes mudanças tecnológicas - a serviço de alguns observa-se a concentração da propriedade privada e a polarização crescente do ponto de vista social. Tal polarização se expressa nos níveis muito desiguais de renda, educação formal e qualificação profissional e se reflete de várias formas nos espaços da metrópole, em que se observa cada vez de forma mais acentuada a presença de espaços residenciais e comerciais exclusivos, a privatização de espaços públicos, com o "fechamento" de ruas e praças para garantir a segurança de setores da população ameaçados pelas "classes perigosas". Tal privatização dos espaços públicos pode ocorrer tanto em áreas centrais do município-sede, onde se encontram os maiores percentuais de famílias de alta renda, como em áreas menos segregadas e menos centrais, onde a presença acentuada da pobreza constitui uma ameaça às famílias de "renda média" que, muitas vezes, "expulsas" das áreas centrais, devido a valores imobiliários incompatíveis com seus salários, reproduzem nos novos locais de residência os processos vigentes nas áreas mais valorizadas.

Esse processo pode ser, também, inserido no contexto que Marcuse (1997) denomina de "cidadela", que serve para designar os grandes condomínios cercados, de casas e apartamentos, em que guardas particulares e sistemas high-tech de segurança buscam garantir que intrusos fiquem "de fora" da vizinhança.

Entre as "cidadelas" detectadas hoje em grandes metrópoles, pode-se perceber algumas habitadas por aqueles que estão no "topo" em termos de poder econômico e político (idem). Outras, no entanto, são ocupadas por famílias "bem-sucedidas", que embora não estejam no topo da escala social, sentem-se vulneráveis em relação aos mais pobres, de cuja proximidade residem e querem manter-se longe deles. A este segundo tipo, Marcuse denomina de "exclusionary enclaves" (1997, p.247).

Considerando-se o quadro mais amplo dos debates teóricos recentes, que colocam a necessidade de rever o modelo de dualização da estrutura socioespacial, para o caso das 
Lúcia M. M. Bógus é socióloga, doutora em Estruturas Ambientais Urbanas pela FAU/USP e professora da FCS/PUCSP. E-mail: lubogus@uol.com.br

Suzana P. Taschner é arquiteta, doutora em Demografia pela FSP/USP e professora da FAU/USP. E-mail: suzana@informatel.com.br

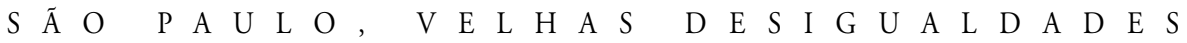

metrópoles brasileiras (Lago,1998), cabem aqui algumas observações com base na análise ainda muito preliminar dos dados.

De fato, esta primeira aproximação aponta para a presença da pobreza em todo o espaço metropolitano, o que indicaria uma estrutura espacial não dual, com o aumento relativo das camadas médias nas áreas periféricas. Entretanto, nossos dados para a RMSP apontam, também, e com força relativa considerável, para a existência de espaços polarizados, onde a presença, seja da população de alta renda e alta qualificação profissional, seja de população de baixa renda e precária qualificação para o trabalho, é pouco permeada por elementos de outras camadas sociais.

É neste contexto que, segundo Lago (1998, p.3), "emergem novas modalidades de segregação socioespacial baseadas na exclusividade residencial e comercial, tanto nas áreas centrais quanto nas periféricas".

Entretanto, se de um lado pode-se falar da existência de espaços quase exclusivos para as categorias superiores/inferiores na escala social, por outro, detecta-se a diversificação da estrutura social e redistribuição no espaço urbano, particularmente das camadas de renda média.

Tais camadas buscam, em geral, instalar-se em áreas próximas ou habitadas por população de alta renda, onde seu peso relativo é importante, estando também dispersas como já foi apontado - por toda região metropolitana, criando espaços sociais mistos ou de estruturação social mais complexa.

Ao longo da pesquisa o confronto das categorias empíricas com os conceitos permitirá apurar o quanto as noções de polarização, fragmentação, exclusão e dual cities permitem apreender e explicar a realidade estudada.

Por enquanto, o que se depreende é a existência de "enclaves sociais" num espaço que tende mais à fragmentação do que à dualização e onde a polarização social é extremamente forte.

\section{REFERÊNCIAS BIBLIOGRÁFICAS}

BETTIN, G. Los Sociologos de la Ciudad. Barcelona: Gustavo Gili, 1982.

BÓGUS, L., MONTALI, L. "A reestruturação metropolitana de São Paulo". Revista Margem, São Paulo, EDUC, n.3, p.159-78, 1994.

BÓGUS, L. (Re)urbanização: por que e para quem? 1988. Tese (Doutorado) - Faculdade de Arquitetura e Urbanismo da Universidade de São Paulo.

—. "Condiçôes de vida e acesso a serviços no contexto das metrópoles paulistas". In: PATARRA, N. et al. Migração, condiçôes de vida e dinâmica urbana. São Paulo 19801993. Campinas: Editora da Unicamp/Fapesp, 1997. p.153-76.

CARDOSO, A . L., RIBEIRO, L. C. Q. Dualização e reestruturação urbana: o caso do Rio de Janeiro. Rio de Janeiro: IPPUR/UfRJ, 1996.

CARDOSO, F. H. O modelo politico brasileiro e outros ensaios. São Paulo: Ditel, 1973.

CASTEL, R. "As armadilhas da exclusão". In: BÓGUS, L.; YASBEK, M. C., WANDERLEY, M. (Orgs.). Desigualdade e a questão social. São Paulo: EDUC, 1997. p.15-48.

CASTELLS, M. The Informational Society. Oxford: Blackwell, 1989.

COULON, A. A escola de Chicago. Campinas: Papirus, 1995.

FARIA, V. Occupational Marginality, Employment and Poverty in Urban Brazil. 1976. Thesis (PhD) - Harvard University. 
Finep/GAP. Habitação popular: propostas metodológicas para intervenção pública em favelas do Rio de Janeiro. São Paulo: Pro-Editores, s.d.

FRÚGOLI, H. O Centro, a avenida Paulista e a avenida Luiz Carlos Berrini na perspectiva de suas associações: atualidade urbana e exclusão social. 1998. Tese (Doutoramento) - Faculdade de Filosofia, Letras e Ciências Humanas da Universidade de São Paulo.

KOHARA, L., ALMEIDA, M. A. P. de. População moradora na rua e a questão urbana. Trabalho apresentado à Escola Politécnica da USP, disciplina PCC - 755. São Paulo, 1995. (Mimeo.)

KOWARICK, L. Capitalismo e marginalidade na América Latina. Rio de Janeiro: Paz e Terra, 1975.

LAGENEST, H. D. B. de (Coord.). "Os cortiços de São Paulo". Revista Anhembi, n.139, jun. 1962.

LAGO, L. C. Estruturação urbana e mobilidade espacial: uma análise das desigualdades socioespaciais na metrópole do Rio de Janeiro. 1998. Tese (Doutoramento) - Faculdade de Arquitetura e Urbanismo da Universidade de São Paulo.

MARCUSE, P. "The Enclave, the Citadel and the Guetto. What has Changed in the Post-Fordist U.S. City”. Urban Affairs Rewiew, Sage Pbl. Inc., v.33, n.2, p.228-64, nov. 1997.

MAUTNER, Y. The Periphery as a Frontier for the Expansion of Capital. Londres, 1991. Thesis (PhD) - University College, Bartlett School of Architecture \& Planning.

MONTALI, L. "Família, Trabalho e Migração". In: PATARRA, N. et al. Migração, condiçôes de vida e dinâmica urbana. Campinas: Editora da Unicamp, 1997. p.261-318.

NUN, J. "Sobrepoblación relativa, ejercito industrial de reserva y massa marginal". Revista Latino-Americana de Sociologia, 4(2), p.178-237, jul. 1969.

OLIVEIRA, F. A economia brasileira: crítica à razão dualista. São Paulo: Cebrap, 1981.

PRETECEILLE, E. Mutations Urbains et Politiques Locales. Paris: CSU, 1993. . "Cidades globais e segmentação social". In: RIBEIRO, L. C. Q., SANTOS JUNIOR, O. Globalização, fragmentação e reforma urbana: o futuro das cidades brasileiras na crise. Rio de Janeiro: Civilização Brasileira, 1994. p.65-92.

São Paulo, Município - Relatório da Comissão de Exame e Inspeção das habitações operárias e cortiços no Distritos de Santa Efigênia. São Paulo, 1894.

SASSEN, S. "The Global City". In: FAINTEIN, S., CAMPBELL, S. Readings in Urban Theory. Oxford: Blackwell, 1997. p.61-71.

SILVA, H. M. B., CASTRO, C. M. P. de. "A legislação, o mercado e o acesso à habitação em São Paulo". In: Workshop Habitação: Como Ampliar o Mercado? Anais...: IPT, 25 a 27 de agosto de 1997. (Mimeo.)

SMOLKA, M. O. "Mobilidade intra-urbana no Rio de Janeiro: da estratificação social à segregação residencial no espaço”. Revista Brasileira de Estudos de População, v.9, n.2, p.97-114, jul./dez. 1992a.

. "Revisitando as relaçôes entre a política habitacional (SFH) e o mercado imobiliário”. Revista Espaço \& Debates, n.36, p.69-76, 1992b.

TABB, W. "As cidades mundiais e a problemática urbana: os casos de Nova York e Tóquio”. In: PRETECEILLE, E., VALLADARES, L. (Coords.). Reestruturação urbana: tendências e desafios. São Paulo: Nobel/Iuperj, 1990. p.183-91.

TASCHNER, S. P., MAUTNER, Y. "Habitação da Pobreza". Cadernos PRODEUR, São Paulo, FAU/USP, n.5, 1982. 
TASCHNER, S. P. "Habitação e demografia intra-urbana em São Paulo". Revista Brasileira de Estudos de População, 7(1), p.3-33, jan.-jun. 1990.

"Changes in the Process of Self-help Housing Production in São Paulo". In: MATHEY, K. Beyond Self-Help Housing. London: Mansell, 1992. p.145-56.

VAN KEMPEN, R., MARCUSE, P. "A New Spatial Order in Cities?" American Behavioral Scientist, p.285-98, nov.-dez. 1997.

VAZ, L. et al. História dos bairros: Saúde, Gamboa, Santo Cristo. Rio de Janeiro: João Fortes Engenharia/Editora Index, 1987.

VAZ, L. História da habitação coletiva no Rio de Janeiro: um estudo da modernidade através da moradia. 1995. Tese (Doutoramento) - Faculdade de Arquitetura e Urbanismo da Universidade de São Paulo.

VIEIRA, M. (Org.). População de rua: quem é, como vive, como é vista. São Paulo: Hucitec, 1992.

\section{ANEXOS}

\section{Nota Metodológica 1}

De acordo com a metodologia adotada no Projeto "Metrópole, Desigualdades Socioespaciais e Governança Urbana" (PRONEX) foram definidas as seguintes categorias sócio-ocupacionais:

1 Ocupações Agrícolas

Ocupaçōes Agrícolas - formada por todas as ocupações agrícolas, e, em relação às categorias criador bovino, proprietário agropecuário e avicultor, apenas as pessoas com renda inferior a vinte salários mínimos mantem-se nesta categoria.

\section{Elite Dirigente}

Grandes empresários - formada pelos empregadores com alto score (renda mais educação), com exceção das ocupações tradicionalmente definidas como de profissionais liberais, e mais os outros empregadores (baixo score) com renda acima de vinte salários mínimos.

Dirigentes do setor público - formada pelas ocupações do alto escaláo do setor público (ministros, magistrados, procuradores, diretores).

Dirigentes do setor privado - formada pelas ocupaçôes de administradores de empresas com alto score e renda acima de vinte salários mínimos.

Profissionais liberais - formada pelas ocupaçóes tradicionalmente definidas como de profissionais liberais (médicos, engenheiros, arquitetos, dentistas, advogados), agregando empregadores e conta própria.

\section{Pequena Burguesia}

Pequenos comerciantes - formada pelos comerciantes empregadores, com renda abaixo de vinte salários mínimos.

Pequenos empregadores urbanos - formada pelos empregadores com baixo score, excluídos os comerciantes, com renda abaixo de vinte salários mínimos.

Comerciantes por conta própria - formada pela ocupação comerciante por conta própria. 


\section{Profissionais de Nível Superior}

Profissionais autônomos de nível superior - formada por profissionais de nível superior, excluídas as ocupaçôes tradicionalmente definidas como de profissionais liberais por conta própria.

Empregados de nível superior - formada por profissionais de nível superior, empregados.

5 Trabalhadores Não-manuais de Nível Médio

Trabalhadores não-manuais em atividades de rotina - formada pelas ocupações que executam atividades de rotina, tais como secretárias, auxiliares administrativos, auxiliares de escritório, recepcionistas.

Trabalhadores não-manuais em atividades de supervisão - formada pelas ocupações que executam atividades de supervisão, tais como assistentes de administração, encarregados de administração, corretores de imóvel, administradores do comércio.

Trabalhadores não-manuais em atividades técnicas e artísticas - formada pelas ocupações que executam atividades técnicas e artísticas, tais como desenhistas, técnicos em contabilidade, caixas, técnicos em energia elétrica, programadores de computação, músicos, fotógrafos.

Trabalhadores não-manuais nas áreas de saúde e educação - formada pelas ocupações diretamente ligadas às áreas de saúde e educação, tais como professores e enfermeiras não-diplomadas.

Trabalhadores não-manuais nas áreas de segurança pública, justiça e correios - formada pelas ocupações diretamente ligadas às áreas de segurança pública (polícia e forças armadas), justiça e correios, tais como investigadores de polícia, oficiais do corpo de bombeiros, praças das forças armadas, carteiros.

\section{Trabalhadores do Comércio e Serviços}

Trabalhadores do comércio - formada pelas ocupações diretamente ligadas às atividades do comércio, tais como vendedores, operadores de caixa, pracistas e representantes comerciais.

Prestadores de serviços - formada pelos trabalhadores que prestam algum tipo de serviço, tais como cozinheiros, mecânicos, cabeleireiros, vigias, porteiros, trocadores, embarcadores, excluídos os profissionais autônomos especializados (mecânicos, sapateiros, motoristas, eletricistas etc.) com renda acima de dez salários mínimos.

\section{Trabalhadores Manuais da Indústria e Serviços}

Trabalhadores manuais da indústria moderna - formada pelos trabalhadores manuais das indústrias do setor moderno: metalúrgica, mecânica, material elétrico, material de transportes, papel, borracha, química, produção de petróleo, farmacêutico, perfume e sabão, editoração gráfica, fumo.

Trabalhadores manuais da indústria tradicional - formada pelos trabalhadores manuais das indústrias do setor tradicional: o restante dos ramos, exceto a construção civil.

Profissionais autônomos - formada pelos trabalhadores manuais autônomos especializados, com renda acima de dez salários mínimos, tais como pintores, pedreiros, costureiros, carpinteiros, marceneiros, sapateiros, cabeleireiros, motoristas, mecânicos.

Trabalhadores manuais da construção civil - formada pelas ocupações diretamente ligadas à construção civil, tais como mestres, ladrilheiros, pedreiros, pintores, serventes de pedreiros. 
8 Trabalhadores da Sobrevivência

Empregados domésticos - formada pela ocupação empregado doméstico, pelas ocupações enfermeiro não-diplomado, motorista e jardineiro, cujo ramo de atividade seja doméstico, e pela ocupação lavadeira, cuja posição seja por conta própria.

Ambulantes - formada pelos feirantes, doceiros, quitandeiros, carroceiros, outras ocupaçōes ambulantes.

Biscateiros - formada pelos guardadores de automóveis, trabalhadores braçais, engraxates.

Tais categorias foram construídas com base nas ocupações classificadas pelo Censo Demográfico de 1980. Considerando-as uma expressão da hierarquia social existente no país, sua espacialização permitirá apreender a desigualdade social no espaço metropolitano paulista.

\section{Nota Metodológica 2}

A espacialização proposta para o estudo das variáveis consideradas partiu da classificação segundo vetores, elaborada pela Emplasa (Empresa Metropolitana de Planejamento) para os municípios da Região Metropolitana de São Paulo, respeitando a contigüidade geográfica. São eles:

Vetor Centro - São Paulo e Osasco.

Vetor Noroeste - Barueri, Cajamar, Carapicuiba, Pirapora do Bom Jesus e Santana do Parnaíba.

Vetor Oeste - Cotia, Itapevi, Jandira e Vargem Grande Paulista.

Vetor Sudoeste - Embu, Embu-Guaçu, Itapecerica da Serra, Juquitiba, São Lourenço e Taboão da Serra.

Vetor Sudeste - Santo André, São Bernardo, São Caetano, Diadema, Ribeirão Pires e Rio Grande da Serra.

Vetor Leste - Mogi das Cruzes, Suzano, Poá, Itaquaquecetuba, Ferraz de Vasconcelos, Guararema, Salesópolis e Biritiba Mirim.

Vetor Nordeste - Guarulhos, Arujá e Santa Isabel.

Vetor Norte - Francisco Morato, Franco da Rocha, Caieiras e Mairiporã.

A B S T R A C T The present paper shows the first results of a research which was sponsored by PRONEX. It supplies a first approach of the social segregation in the Great São Paulo, showing the residential distribution of some characteristics of the head of the family - socioprofessional category, sex, age, years of study, race and income, as well as some domicile characteristics. The map shows a great concentration of the leading elite, bourgeoisie and superior professionals in the central area of the capital. On the other hand, the survival workers live preferentially in some areas of the peripheral cities. As general results, the heads of families on Great São Paulo still are predominant masculine (81,70\%), whites (68,01\%), with low degree of formal instruction (10,21\% without no year of formal school). The paper shows these results in maps, scanning the social segregation.

K E Y W O R D S Metropolis; spatial segregation; intra-urban dynamics. 